\title{
Public-Union Sector Politics and the Crisis of Education in South Africa
}

\author{
Moeketsi Letseka ${ }^{1}$, Bongani Bantwini ${ }^{2}$, Ethel King-McKenzie ${ }^{2}$ \\ ${ }^{1}$ College of Education, University of South Africa, Pretoria, South Africa \\ ${ }^{2}$ Bagwell College, Kennesaw State University, Atlanta, USA \\ Email: letsem@unisa.ac.za
}

Received September $1^{\text {st }}$, 2012; revised October $4^{\text {th }}$, 2012; accepted October $14^{\text {th }}, 2012$

\begin{abstract}
This paper reflects on public-sector unions in South Africa with a view to highlighting teacher unionization's contribution to South Africa's education crisis. South Africa's teaching profession is highly unionized. The largest teacher union, the South African Democratic Teachers Union (SADTU) is affiliated to the Congress of South African Trade Unions (COSATU). The latter is a partner in the ruling tripartite alliance that includes the African National Congress (ANC) and the South African Communist Party (SACP). Worldwide most public-sector unions are known to prop up left-wing political organizations. SADTU is no exception. But this paper shows that SADTU organizes teachers at the expense of teaching and learning in a country whose education system has been described as "a crisis" and "a national disaster" whose schools are "dysfunctional". The paper contemplates on the possibility of borrowing from business models to "redesign" or "reengineer" the country’s ailing education system into an efficient system.
\end{abstract}

Keywords: SADTU; Global Union Politics; Reengineering; South Africa; Teachers’ Strikes; Education Crisis

\section{Introduction}

Harvard Business Review (HBR) of January-February 2011 ran a Spotlight on "Business Model Innovation", while The Economist of 8-14 January 2011 ran a lead story on "PublicSector Unions". The two articles are pertinent to South Africa's ailing and dysfunctional education system. South Africa's teaching profession is highly unionized. There are four major teacher unions: the South African Democratic Teachers Union (SADTU), the National Professional Teachers Association of South Africa (NAPTOSA), the Suid-Afrikaanse Onderwysunie (SAOU), and the National Teachers Union (NATU) (Fiske \& Ladd, 2004). SADTU is by far the biggest, boasting of over 240,000 members. It is affiliated to the Congress of South African Trade Unions (COSATU). The latter is a member of the ruling tripartite alliance comprising the African National Congress (ANC) and the South African Communist Party (SACP). Chisholm (2003) argues that SADTU is not only the most powerful union, but is also closest to the government. Born in the years of the anti-apartheid struggle, the union defined itself in opposition to the then racially-based professional associations as being concerned with issues wider than the narrow workplace and salary concerns of these associations. After the transition to democracy in April 1994 most of SADTU leadership was catapulted to senior positions in the post-Apartheid government. And yet notwithstanding the union's political ties with government the two are often at loggerheads over labor issues.

The opening lines of 1960s legendary American folk rock band Buffalo Springfield's song "For What It's Worth' read: There's something happening here/what it is ain't exactly clear". With South Africa's education system we all know "there's something happening here". The only thing different is that what it is "is exactly clear". And that is, the system is dys- functional. It has been described as "a crisis" (Fleisch, 2008; Ray, 2008), and "a national disaster" (Bloch, 2009) that is "in tatters" (Monare, 2010). It is "inefficient and makes ineffective use of resources" (Centre for Development and Enterprise, 2007). As a result it is "generally performing poorly" (Van der Berg, 2007) and lags "far behind even much poorer countries" (van der Berg, 2008). Scores obtained by South African school learners in international tests and evaluation in literacy and numeracy are much lower than those obtained by learners in the East Asian tigers of Hong Kong, Singapore and South Korea, whose governments spend proportionately much less on schooling than South Africa. Van der Berg (2007: p. 854) notes that South Africa's performance in the Grade 6 education evaluation test conducted by the Southern African Consortium for Monitoring Educational Quality (SACMEQ II) in 2000 placed it in the bottom half of the 14 participating countries on both reading and mathematics. Most pupils at Grade 6 level performed at Grade 3 level or worse in mathematics tests (Moloi, 2005). Against this background our view is that South Africa's education system needs "reengineering". The idea of business "reengineering" was given prominence by Michael Hammer and James Champy (2003) in their book, Reengineering the Corporation: A Manifesto for Business Revolution. Others have proposed the idea of "reinvention" (Nunes \& Breene, 2011; Govindarajan \& Trimble, 2011), with a view to turning conventional wisdom on its head and learning to focus on fixing what doesn't appear to be broken.

In this article we debate global public-sector unionism and speculate on its impact on the crisis of education in South Africa. We are concerned that SADTU tends to flex its political muscles to mobilize teachers to strike over salary increases, but that the strikes and stay-aways often occur at the expense of teaching and learning, which are compromised for months on 
end. This does not augur well in a country whose education system is dysfunctional and cannot compete with systems in its much poorer neighboring countries. Our view is that South Africa's education system needs to be "redesigned" and "reengineered". It might be argued that models for "redesigning” and "reengineering" businesses are intended for profit making business enterprises in the private sector and might not be appropriate to public education, which resides in the public sector. While there might be substance in the argument it is our contention that important lessons can be learned from private business "redesigning" and "reengineering" for the purpose of developing sustainable strategies for improving the provision of quality public education. We explore the potential of such business models. First, we sketch the global public-sector union scenario. Second, we comment on SADTU's political muscles and the implications thereof for the delivery of quality public education, especially in black schools. Third, we speculate on the possibilities of "reinventing" and "reengineering" South Africa's ailing and dysfunctional education system. And finally, we offer some concluding remarks.

\section{The Global Public-Sector Union Scenario}

Currently the global union sector is experiencing mixed fortunes. On the one hand union membership in the private sector has collapsed over the past 30 years (from $44 \%$ of the workforce to $15 \%$ in Britain and from $33 \%$ to $15 \%$ in America). On the other hand union membership in the public sector has remained buoyant. The Economist (2011) notes that over half the workers in Britain are unionized. In America the figure is currently 36\% (compared with just 11\% in 1960) while in Canada public-sector union density has increased from 12\% in 1960 to more than $70 \%$ today. What magnifies public-section union membership and power is not only the unions' ability to shut down monopolies and force some of the businesses to go bust, but also the unions' political clout over some of the employers. Politicians are prone to acquiescing to public-sector union demands by awarding generous pensions, adding more holidays or dropping proposed reform initiatives. The Economist (2011) notes that "wages are on average higher in the state sector, pensions hugely better, and jobs far more secure". To any commentator on the South African education system and teacher unions The Economist observations above are like déjà vu. As mentioned above South Africa's teaching profession is highly unionized. SADTU routinely organizes strikes and protest marches to "demand" salary increases and related benefits, often above market value, notwithstanding National Treasury's view that public service wages account for $32 \%$ of the country's annual budget of R850 billion. National Treasury is clear that government needs to reprioritize spending and rein in the budget deficit, which has reached a 17-year high of $6.2 \%$ of gross domestic product in the year through March (Monana \& Hlongwane, 2010).

Teachers' strikes are a global phenomenon. The Economist (2011: p. 22) reports that in Brazil, teachers have organized huge marches against government's attempts to link promotion to performance and to reduce the number of days when they can take off without notice. In Greece teachers have fought four consecutive education ministers from different parties over performance reviews. In Britain teachers are trying to kill "free" schools, which can be set up outside local-authority control, while in the United States of America (USA) teachers continue to fight against charter schools (which escape union rules about pay and promotion) and scholarship schemes (which give choice to parents). As is to be expected this trend is also a characteristic feature of the South African public-sector union. For instance, SADTU has vehemently opposed the Department of Education (DoE)'s introduction of the scheme to monitor and evaluate the performance of the schools and the teachers. As The Economist (2011) points out, ahead of these battles lies a huge opportunity - to redesign government and focus it on productivity and delivery of better services. We will come back to the notions of "redesign" and "reengineer" in more detail below. The need to focus on productivity and delivery of better services is especially pertinent to South Africa where the education system is dysfunctional, unemployment is high and inequality is rising.

The Economist (2011: p. 21) notes that "public-sector unions are some of the world's most powerful interest groups. Many of them have large membership and comparably large budgets”. In many countries public-sector unions prop up left-wing political organizations. For instance, Britain's Labor Party gets $80 \%$ of its funding from public-sector unions (which also, in effect, chose its leader). The new leader of the Labor Party, Ed Miliband owes his job to trade union votes. In the US, teachers accounted for a tenth of the delegates at the Democratic convention in 2008. According to The Economist (2011), Andy Stern, head of the Service Employees International Union, was the most frequent guest at the White House in the first six months of Barack Obama's presidency. In South Africa, SADTU's former senior office bearers have gone on to become longserving cabinet ministers and senior government officials in the post-apartheid democratic government.

Unions make it almost impossible for employers to sack incompetent workers (The Economist, 2011: p. 22). Indeed "politicians have repeatedly given in, sneakily-by swelling pensions, adding more holidays or dropping reforms" (The Economist (2011: p. 9). Politicians are under constant pressure to seek more diplomatic solutions to public-sector union demands in order to avoid tension and protracted labor disputes. History shows that politicians who become confrontational soon realize that they do so at their own peril. Greek education minister Marietta Giannakou lost her seat for insisting on teacher accountability. In the US, Michelle Rhee, chancellor of the school system in Washington DC closed failing schools, fired more than 200 ineffective teachers and principals, and advocated merit pay. In response the unions used their political muscles to bring about her resignation. During 2000-2010 the Los Angeles school district spent $\$ 3.5 \mathrm{~m}$ trying to get rid of 33,000 "problem teachers". In the end it only succeeded in getting rid of a paltry five. Worldwide public-sector unions have successfully extracted excellent benefits for their members and forced governments to grant unionized workers light workloads and generous pensions, while also making it impossible to sack incompetent and underperforming workers. Invariably public-sector workers earn, on average, a third more than their private-sector counterparts. The Economist (2011: p. 22) notes that in America teachers teach for a mere 180 days a year, while in Brazil teachers have the right to take 40 days off a year-out of 200 working days-without giving an explanation or lose of a centavo of pay. Unionized South African teachers spent less time in class teaching (Chisholm et al., 2005; Makola, 2005). 


\section{SADTU's Public Muscles and Their Implications for Education}

The international public-sector union picture sketched above resonates with South Africa's teacher unions' scenario. As mentioned above, SADTU is the largest teacher union in South Africa boasting of 240000 members, mostly black and African. This number constitutes more than $70 \%$ of educators in the whole of South Africa's teaching sector (Zengele, 2009). We also mentioned that SADTU is a strategic political partner in the ANC-led ruling tripartite alliance by virtue of its affiliation to COSATU. The tripartite alliance represents the predominantly black and African political constituency that was previously disadvantaged and excluded from decision-making processes during apartheid, but which now constitutes an unassailable majority in the South African parliament. It is this majority that votes bills into laws and discussion documents into national policies.

We mentioned above that globally public-sector unions prop up most left-wing political organizations. In SADTU's case its former president, Membathisi Mdladlana became minister of labor when the ANC was voted into government in April 1994 (Zengele, 2009). Mdladlana remains the longest serving minister in South Africa's post-apartheid government having served as labor minister during the presidencies of Nelson Mandela, Thabo Mbeki and Kgalema Motlanthe, who was acting president when Mbeki was recalled by the ANC in September 2008. ${ }^{1}$ Mdladlana was only relieved of his ministerial duties by President Jacob Zuma towards the end of 2010. Another former SADTU senior official, Duncan Hindle, joined the Department of Education in 1996 as chief director and was eventually promoted to the position of director general in 2005. Former SADTU Secretary General Thulas Nxesi, was made member of parliament in 2009 (Zengele, 2009). He was appointed deputy minister of rural development and land reform in 2010, and subsequently promoted to minister of public service during the 2012 cabinet reshuffle.

SADTU's position as a key partner in the ruling tripartite alliance has serious implications for appointments to key strategic posts in the schools. In their Human Sciences Research Council (HSRC) study on retention and attrition of teachers in the North West Province Diko and Letseka (2009: p. 323) report on abuses of recruitment and promotion processes for post levels 2 (head of department) and post level 3 (deputy principal) by teacher unions, especially SADTU and union-aligned local education officials. This often manifests in behind-the-scenes canvassing by union leaders for their preferred candidates. And while the interview questions for such posts are supposed to be tightly managed by the District Education Office and by law unions are supposed to only serve as observers during the interview process, Diko and Letseka (2009) report on routine and convenient leaking of classified details to the unions' preferred candidates to enable them to sail through the interview. Zengele (2009) writes that the SADTU strike of June 2009 was primarily a protest against the Gauteng Department of Education's refusal to endorse the appointment of two principal who were SADTU's preferred candidates. Ironically one of the union's preferred candidates had 18 years experience as an administrative clerk and only six months as an educator, while the other was a wife to a SADTU official with only a teaching diploma.

${ }^{1}$ See Frank Chikane (2012) Eight days in September: The removal of Thabo Mbeki. Johannesburg: Picador Africa.
The candidates the union sought to sideline were experienced educators who possessed postgraduate education degrees.

Notwithstanding its strategic position in the ruling tripartite alliance SADTU does not hesitate to mobilize its members to go on strike over salary increases. The strikes are often marked by violent attacks on those that are perceived to be dissenters or scabs. Fleisch (2010: p. 123) argues that SADTU members are willing to use intimidation and threats as tactics with the department's officials and schools, and SADTU militants assume de facto authority in relation to departmental functions such as district officials' work and disciplinary action against schools that bar learners from writing examinations. Concomitantly, SADTU strikes and protest marches are often carried out with total disregard for their impact on teaching and learning (Mbabela, 2010; Lelliott \& Mbabela, 2010). For instance, in 2000 the DoE introduced the National Policy on Whole School Evaluation (WSE) to monitor and evaluate the performance of the schools and the teachers (Jansen, 2004). The WSE was designed "to establish standardized instruments and procedures for monitoring school performance and establishing the support needs of schools” (Taylor, Muller, \& Vinjevold, 2003: p. 126). The policy was meant to be supportive and developmental rather than punitive and judgmental. It was not intended to be used as a coercive measure, but would ensure that policies are compliant with it. It would facilitate support and improvement of school performance using approaches of partnerships, collaboration, mentoring and guidance. Regardless of all these assurances SADTU waged a bitter battle to prevent such testing and evaluation and to protect its members from being evaluated, some of whom have in fact been described as "scoundrels" (Monare, 2011). In 2003 the East Rand Gauteng branch of SADTU refused WSE into their classrooms (Weber, 2005). By the time the June 2009 Soweto Branch of SADTU "strike action came to an end, hundreds of teachers had missed more than two weeks of work, thousands of school children, including learners in the final years of secondary school, had missed their mid-year examinations, and a number of principals and teachers had been assaulted and intimidated" (Fleisch, 2010: p. 117).

On 18 August 2010 SADTU embarked on a full scale "indefinite strike" over salaries. The union demanded an $8.6 \%$ salary adjustment, R1000 housing allowance, and an equalization of medical aid (SADTU media statement, 17 August 2010). The strike resulted in a total shut down of schools until 6 September 2010 when it was eventually suspended. Grade 12 (matric) examinations were due to start on 26 October 2010. Bloch (2008: p. 129) notes a tendency for relations with teacher unions to be conflict-based "labor relations" rather than processes of mutual professional development. The only language known by unions to achieve their goals is: "we demand". In most SADTU-organized strikes the DoE is known to accede to the union's demands. This can be attributed to SADTU's historical links with South Africa's liberation struggle politics as sketched by Chisholm (2003) above, and the fear by government that protracted teachers' strikes would have a negative impact on time spent on teaching, preparation and planning (Chisholm et al., 2005; Makola, 2005).

Given the above account it is no wonder South Africa's education system has been described as "a crisis" (Fleisch, 2008) and "a national disaster" (Bloch, 2009) that is "in tatters" (Monare, 2010), that is "inefficient and makes ineffective use of resources" (CDE, 2007), and is "essentially dysfunctional" (Taylor, 2006; Bloch, 2010). In its "Special Report on South 
Africa: Last in Class”, The Economist (2010) cites Graeme Bloch, who describes South Africa's education system as a "national disaster". In his book, The Toxic Mix: What's Wrong With SA's Schools and How to Fix It, Bloch (2009: p. 88) is categorical that "schooling in South Africa is a national disaster". He writes that a toxic mix of factors conspires to keep South Africa's schools in a state of disaster. Half of all pupils drop out before taking their final "matric" examinations. Out of a thousand people born between 1980 and 1984, an estimated 984 entered Grade 1, but 12 years later only 456 or $46 \%$ reached Grade 12 (see Figure 1). Bloch notes that barely 11\% of this total gets a good enough pass to qualify for university. The rest are functionally illiterate and innumerate, requiring intensive first-year remedial classes to bring them up to scratch. Taylor (2006) argues that good schools are ordered institutions which cultivate a strong work ethic, the ability to perform under pressure, and a sense of initiative and responsibility; they teach children, both in the way they operate and in the values they espouse, that expertise and principle, not patronage and corruption, are the paths to sustainable success. Such schools are places where future citizens learn to appreciate cultural diversity and resolve their differences through the application of rational rules. Sadly in South Africa such schools are rare.

For Block (2009), there is no shortage of evidence on how badly the South African education system is performing. The stark reality is that some $60 \%-80 \%$ of the schools today might be called "dysfunctional" (Bloch, 2009: p. 17). Some $41 \%$ of schools are in poor or unacceptable state of maintenance (Bloch, 2009: p. 81). The dysfunction is manifest in South African learners' poor performance in international evaluation tests on literacy, numeracy and science ability. In their evaluation of South Africa's performance in the 2003 Trends in International Mathematics and Science Study (TIMSS), Reddy et al., (2006) note that South Africa had one of the highest gross national incomes (GNI in US Dollars) per capita of the group, yet it had the lowest average mean score in mathematics and science. South Africa came last out of the 50 countries participating in the 2003 TIMSS study, and had the lowest scores in numeracy in the Monitoring of Learning Achievement (MLA) (Reddy, 2006: p. 139). This is confirmed by Kivilu (2006: p. 36) who notes that TIMSS ranks South Africa last in proficiency levels. About 69 per cent of South African learners who took part in TIMSS did not achieve the lower-quarter benchmark. Grade 6 education evaluation tests conducted by SACMEQ II in 2000 placed South Africa in the bottom half of the 14 participating countries in both reading and mathematics, behind countries such as Botswana, Kenya, Lesotho, Mauritius, Mozambique, Namibia, Seychelles, Swaziland, Tanzania, Uganda, Zambia, and Zimbabwe (Bloch, 2009). More than half of grade 6 students perform at a grade 3 level or lower in mathematics (Van der Berg, 2007; Moloi, 2005).

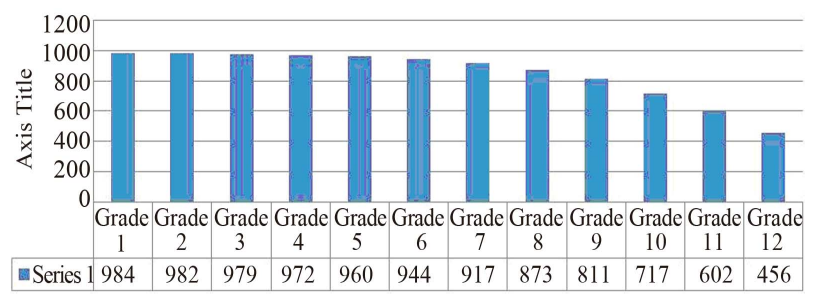

Figure 1.

Survival and dropout rate: 1980-1984 birth cohort.
Fleisch (2008) reviewed numerous "authoritative studies on reading and mathematics achievement” conducted to test South Africa's primary school learners. These include among others, the Monitoring Learning Achievement (MLA, 1999), the Early Reading Workshop (ERW, 1999), the Quality Learning Project (QPL, 2001), the District Development Support Program (DDSP, 2001), the TIMSS 2003, the Family Literacy Project (FLP, 2004), the SACMEQ II, 2005, and the Progress in International Reading Literary Study (PIRLS, 2006). While the studies used different "standards" to measure achievement, they all point to the predicament of extremely low average primary education achievement levels (Fleisch, 2008: p. 30). The vast majority of children attending disadvantaged schools do not acquire the basic level of mastery in reading and mathematics.

Reporting on the crisis of schooling in the Eastern Cape Province, ${ }^{2}$ Capazorio (2011) writes that due to financial mismanagement the provincial DoE cut essential services such as school transport, which ensure that more than 100,000 pupils from rural settlements get to and from school each day. The department also cancelled the school nutrition program, which ensures that 1.6 million pupils get at least one meal a day. A concerned opposition party member made the followings remarks in the provincial legislature:

A child gets up at 4 am, walks $12 \mathrm{~km}$ to school, gets there hungry and there is nothing to eat. Then he sits in a classroom with no teacher. He can't concentrate any way because he is so hungry and tired, then he must walk back home. Is that fair? It is a disgrace (Feris, 2011).

In 2010 Feris (2011) reported on schools in the province that were destroyed by a tornado. In 2011 she noted that despite promises by the provincial DoE, one of the schools was never rebuilt, nor was temporary shelter erected. At another school the provincial DoE provided tents to house the pupils but failed to pay the supplier, who removed the tents, leaving more than 200 pupils to be taught in the open. When schools reopened in January 2011 the provincial DoE had terminated the contracts of 4219 temporary teachers filling vacant posts at critically understaffed schools. Permanent incumbents of the posts were still on payroll yet they were not teaching. SADTU demanded that all temporary teachers whose contracts were terminated be reinstated. At the time of writing only 1000 teachers had been reinstated. Monare (2011) argues that SADTU exploits black education as a bargaining chip to protect its members. To reiterate our own rendition of Buffalo Springfield's "For What It's Worth' above, there's something happening here/what it is, is exactly clear”. South Africa's education system is dysfunctional. We noted in the introduction that the earlier SADTU defined itself as "concerned with wider issues than narrow workplace and salary concerns". Ironically, the current SADTU mines the very narrow salary concerns to render education ungovernable.

The national DoE (2007a: p. 29) acknowledges the crisis in education: "the evidence is overwhelming that teaching and learning within the system as a whole are in crisis". Out of 24,717 public schools in the country, 19,550 or $79 \%$ are in need of basic facilities such as chairs and desks; 20,961 or $84.8 \%$ do not have laboratories, while 19,465 or $78.7 \%$ do not have libraries (The Star, 2011). These are staggering percentages. The

\footnotetext{
${ }^{2}$ The Eastern Cape Province is the poorest performing province in education in the country. It has been described as the province most in need of infrastructural development like clean water and sanitation, and improvement of life circumstances such as employment creation and family planning (see Letseka, 2010).
} 
DoE (2007b) draws on a UNESCO (2007) report that picks out poverty as "a significant obstacle to children's education". While there might be substance in the "poverty thesis" our view is that to push it as the main reason for the dysfunction in education is a flawed logic that only obfuscates important predictors of school success. As Hofmeyr and Oberholzer (2011) rightly point out, teacher commitment (the culture of teaching), time spent in class delivering quality teaching and learning (time on tasks), teacher knowledge of subject content, and full coverage of the curriculum, are some of the more accurate predictors of school success. Gauthier and Dembélé (2004) concur. They argue that several decades of pedagogical research show that what teachers do in the class is undoubtedly the key educational determinant in student learning and achievement. Ironically, the HSRC research we mentioned earlier shows that South African teachers generally spent very little time in class teaching (Chisholm et al., 2005). This has prompted South Africa's president Jacob Zuma to call for the three Ts (that is, prioritization of teachers, textbooks and time on tasks). Even then there is evidence that the three Ts campaign might not work in difficult-to-manage provinces such as the Eastern Cape and Limpopo. Fleisch (2008: p. 121) argues that "irrespective of children's social characteristics, their access to "social capital”, the general state of health and welfare, or familiarity with the dominant language of schooling, the underlying or fundamental problem in South African education is about what happens inside the classrooms of our nation”. Teacher quality is the most important leaver for improving student outcomes. The best performing systems ensure quality teaching by valuing teachers as professionals, selecting candidates for the profession through strict processes and monitoring their performance at all stages of their training and professional activities Mosselson (2008: p. 4).

Given overwhelming evidence that in South Africa teachers spent less time in classes teaching, that classes are likely to be disrupted by routine teachers' strikes over salaries, and recently the failure to deliver books on time to schools in Limpopo (at the time of writing, in July, basic education minister was still sorting out delivery of books to schools), the result is cohorts of underprepared school leavers. Research on schooling in South Africa provides ample evidence of under-preparedness of matric students (Slonimsky \& Shalem, 2006; Moll, 2004; Nyamapfene \& Letseka, 1995). Slonimsky and Shalem (2006: pp. 46-47) argue that normally students who matriculate are expected to be highly practiced in working on text-based realities and creating their own text-based realities through writing. But a significant proportion of students currently enrolling in higher education do not appear to have mastered properties of textbased realities. They tend to follow a series of pervasive patterns in their approach to texts and epistemic practices when they first engage in university study-verbatim reproduction or plagiarism; a tendency to focus on examples rather than on principles; a tendency to write from a highly subjective viewpoint without depersonalizing; a failure to pull out arguments in text or cast them; a tendency to include anecdotes as a justification for claims, and a tendency to be prescriptive or normative when asked to be analytic. Other researchers have attributed this under-preparedness to lack of the necessary "epistemological access" for higher education teaching and learning (Boughey, 2005; Morrow, 1992). Our view is that the destabilizing effect of teacher unions as well the DoE's indecisiveness need structured and concerted intervention.

\section{What's to Be Done?}

Block (2009: p. 24) asks pertinent questions to South Africa's education dilemma: how should we fix the schools? What will make the difference and open access to quality education for all children? These questions imply that South Africa's system needs radical “redesign” or “reengineering”. For O’Looney (1993: pp. 376-377), at the heart of redesigning any education system is the notion of changing outdated rules and fundamental assumptions. "Redesigning" means re-examining assumptions and shedding rules of work that are based on outdated notions about technology, people, and organizational goals. The notion of "reengineering" is attributed to Michael Hammer and James Champy's (2003) corporate philosophy cogently articulated in their book: Reengineering the Corporation: A Manifesto for Business Revolution. Hammer and Champy (2003) define "reengineering" as the fundamental rethink and radical redesign of business processes to generate dramatic improvements in critical performance measures-such as cost, quality, service and speed (see Figure 2). "Reengineering" requires people running companies and working in them to change how they think as well as what they do. It requires companies to replace old practices with entirely new ones. It focuses on breakthroughs - quantum leaps forward, and the creation of value.

In an earlier publication Hammer (1990: p. 2) argues that "instead of embedding outdates processes in silicon and software, we should obliterate them and start over. We should "reengineer" our businesses by using the power of modern information technology to radically redesign our business processes in order to achieve dramatic improvements in their performances". "Reengineering" is an all-or-nothing proposition with an uncertain result (Hammer, 1990: p. 2). Managers must switch from supervisory roles to acting as facilitators, enablers, and people whose jobs are the development of people and their skills so that those people will be able to perform value-adding processes themselves (Hammer \& Champy, 2003: p. 77). For many companies "reengineering" is the only hope for breaking away from antiquated processes that threaten to drag them down. This is because "at the heart of reengineering is the notion of discontinuous thinking-of recognizing and breakingaway from the outdated rules and fundamental assumptions that underlie operations” (Hammer, 1990: p. 4). In the reengineered status quo "managers are not the deciders of the fate of employees; customers are. The company does not close plants or lay off workers; customers do, by their actions and inactions” (Hammer, 1996: p. 27). For Hammer (1990: p. 4), most business processes and structures are outmoded and obsolete; fragmented and piecemeal, and lack the integration necessary to maintain quality and service. They are burdened with layers of unproductive overheads and armies of unproductive workers (Hammer, 1990: p. 8), and they are "breeding grounds for tun-

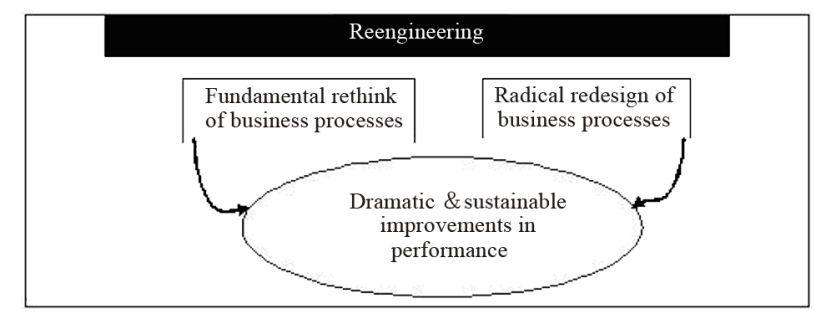

Figure 2.

The reengineering Concept. 
nel vision, as people tend to substitute the narrow goals of their particular departments for the larger goals of the process as a whole" (Hammer, 1990: p. 4).

To successfully reengineer, companies need a business model. But what is "a good business model"? What are characteristics of a "good business model”? Casadesus-Masanell \& Ricart (2011: p. 102) argue that "a business model should consist of a set of managerial choices and the consequences of those choices". It should meet the following criteria a) It must be aligned with company goals: the choices made while designing a business model should deliver consequences that enable the organization to achieve its goals; b) It must be selfreinforcing: the choices that executives make while creating a business model should complement one another; there must be internal consistency. When there is a lack of reinforcement, it should be possible to refine the business model by abandoning some choices and making new ones; and c) It must be robust: a good business model should be able to sustain its effectiveness over time by fending off threats and avoiding imitation by competitors (Casadesus-Masanell \& Ricart, 2011: p. 102).

Govindarajan and Trimble (2011) suggest that CEOs must apply a diagnostic assessment of their companies' vulnerability. They propose that CEOs create three boxes: "Box 1: Manage the Present”, "Box 2: Selectively Forget the Past”, and "Box 3: Create the Future" (see Figure 3). Box 1 is for preservation. It should contain all the forces of change the company faces: technology, customer demographics, regulation, globalization, etc. That is, all those forces that are intended to improve today's business performance. Box 2 is for destruction. It should contain all those forces aimed at stopping something: underperforming products and services, obsolete policies and practices, and outdated assumptions and mindsets. Box 3 is for creation. It should contain all those forces that prepare the organization for long-term growth and development. Striking a healthy between the three boxes is the CEO's most important task. For Govindarajan and Trimble (2011: p. 109), most companies overwhelmingly favor box 1. But forward-looking CEOs tend to strike the right balance. They manage the present efficiently, systematically throw away some of the old practices and assumptions if they deem these to hinder progress, and create a prosperous future for their companies.

The pertinence of these views to South Africa's education system cannot be overemphasized. The DoE's failure to deliver quality education and its paralysis by teacher unions' demands suggests that the bigger picture of educating the young people has been lost. How can "reengineering" help reshape South Africa's education system? How can the national DoE take that quantum leap of shifting from outdated assumptions and shedding rules of work that are based on outdated notions about technology, people, and organizational goals? (O’Looney, 1993: p. 377). For over 18 years the DoE has been stuck in Box 1 and not doing a good job of "managing the present" either. The system is dysfunctional and underperforms compared to the education systems of Hong Kong, Singapore and South Korea, as well as those of neighboring African countries such as Botswana, Kenya, Lesotho, Mauritius, Mozambique, Namibia, Seychelles, Swaziland, Tanzania, Uganda, Zambia, and Zimbabwe. These countries spent much less on schooling than South Africa, yet their learners outperform South Africa's learners in international evaluations and tests (Bloch, 2009; Shindler, 2008; van der Berg, 2008, 2007; Reddy et al., 2006; Moloi, 2005).

This is not unusual. As Govindarajan and Trimble (2011: p. 109) observe, "most companies overwhelmingly favor Box 1 " and ignore destruction and creation until it is too late. South Africa's national DoE has followed obsolete educational practices and outdated assumptions and mindsets. This does not augur well for the country's competitiveness on the global market stage (Joseph, 2003; Lall \& Pietrobelli, 2002). How can the country's education system be "reengineered"? What is it that her neighbors are doing right that she is not? The answer to these questions is fairly simple. These countries are good at inspiring their teachers' commitment (the culture of teaching). Their teachers spent more time in class teaching (time on tasks). They are generally qualified. They possess the basic knowledge of subject content, and receive the necessary support to enable them to be efficient at what they do. These practices are known as the more accurate predictors of school success (Hofmeyr \& Oberholzer, 2011).

Effecting change in a public good such as education is not easy. This is because the education enterprise is complex and contested (Bloch, 2009; Egan, 1992; Enslin, 1993; Wilson, 1988). As Bloch (2009: p. 152) reminds us, the brutal truth is that education is a complex field. Enslin (1993: p. 3) contends that education is a complex and contested concept that picks out a variety of activities, including centrally teaching and learning. Similarly Wilson (1988: p. 84) argues that the education enter prise is inextricably bound up with concepts and values that are unclear, controversial, and hence very much in need of examination. For Egan (1992: p. 646), education is difficult, con-

\begin{tabular}{|c|c|c|c|}
\hline & $\begin{array}{l}\text { BOX } 1 \\
\text { MANAGE THE } \\
\text { PRESENT }\end{array}$ & $\begin{array}{c}\text { BOX } 2 \\
\text { SELECITVELY FORGET } \\
\text { THE PAST }\end{array}$ & $\begin{array}{c}\text { BOX } 3 \\
\text { CREATE THE FUTURE }\end{array}$ \\
\hline & $\begin{array}{c}\text { YOU ARE } \\
\text { ACCUSTOMES TO } \\
\end{array}$ & $\begin{array}{c}\text { YOU MUST RECOGNIZE } \\
\text { THAT } \\
\end{array}$ & SO THAT YOU CAN \\
\hline STRATEGY MAKTING & Data-driven analysis & $\begin{array}{l}\text { Rich data about the future are } \\
\text { not available, The best you } \\
\text { can do is to consider ling-term } \\
\text { trends and potential nonlinear } \\
\text { shifts. }\end{array}$ & $\begin{array}{c}\text { Create a separate, parallel } \\
\text { strategy-making process for } \\
\text { box 3. Involve non-traditional } \\
\text { voices. }\end{array}$ \\
\hline A CCOUNTABILTY & $\begin{array}{l}\text { Strict accountability } \\
\text { for results }\end{array}$ & $\begin{array}{l}\text { The alte mative to } \\
\text { accountability for ressults is } \\
\text { not anarchy. It is a different } \\
\text { kind of accountability. }\end{array}$ & $\begin{array}{l}\text { Hold leaders of box } 3 \text { projects } \\
\text { accountable for running } \\
\text { disciplined experiments. }\end{array}$ \\
\hline $\begin{array}{l}\text { ORGANZA TIONAL } \\
\text { DESIGN }\end{array}$ & Rerfect alignment & $\begin{array}{l}\text { An organization that is } \\
\text { perfectly aligned can operate } \\
\text { only in box } 1 .\end{array}$ & $\begin{array}{l}\text { Create zero-based, custom- } \\
\text { built subunits for box } 3 \\
\text { projects. }\end{array}$ \\
\hline
\end{tabular}

Figure 3.

Diagnostic Assessment of Companies’ Vulnerability. 
tentious, and radically incoherent. No one can claim to know exactly what will make a difference and what will work at a broad systemic level (Bloch, 2009: p. 167). However, Bloch is optimistic that there are many things about education that can be said. For instance, are there ways in which schools can play a part in the revival of communities and creation of a better life for all? The trouble with South Africa's education system is that there are not enough inspired, knowledgeable, dedicated and committed teachers to staff the schools (Bloch, 2009: p. 168). Thus for Bloch (2009: p. 169), improving the quality of teachers, helping teachers teach well, is the most urgent task. More than anything else, what happens at the coalface of interaction between teacher and pupil is the key. Bloch suggests a whole package of attempts to enthuse, support, train, renew, and encourage a new teaching corps, as well as to establish nonnegotiables on agreed and acceptable behavior. We couldn't agree more. "Reengineering” South Africa's education system requires a total change of mindset by government, teachers, parents, and learners, but most centrally teacher unions.

\section{Conclusion}

In this article we have debated global public-sector unionism and its implications on the crisis of education in South Africa. We noted that SADTU, which has powerful political links with government routinely mobilizes its members to go on strike, often at the expense of teaching and learning. We showed that due to SADTU's strike actions and the national DoE's indecisiveness the country's education system is "a crisis" and "a national disaster". It is "in tatters"; "inefficient and makes ineffective use of resources"; it is "generally performing poorly" and lags "far behind the poorer countries" such as Botswana, Kenya, Lesotho, Mauritius, Mozambique, Namibia, Seychelles, Swaziland, Tanzania, Uganda, Zambia, and Zimbabwe, which spend much less on education than South Africa.

We drew on Michael Hammer and James Champy's Reengineering the Corporation to suggest that South Africa's education system needs a fundamental rethink and a radical redesign in order to generate dramatic improvements in critical performance measures such as cost, quality, service and speed. The country's dysfunctional education is an indictment of the ANCled tripartite alliance which commands over $70 \%$ majority in the country's parliament. Over $80 \%$ of the dysfunctional schools are predominantly in the black townships and rural areas, which are key political constituencies of the ruling tripartite alliance. It is ironic that the schools are under constant threat of strike action by SADTU, a critical political partner in the ruling tripartite alliance. Against this contradictory and illogical status quo it is our view that South Africa's education system can benefit immensely from Hammer and Champy's idea of "reengineering”.

\section{REFERENCES}

Bloch, G. (2009). The toxic mix: What's wrong with SA's schools and how to fix it. Cape Town: Tafelberg Publishers.

Bloch, G. (2008). The complexity of systems change in education. In S. Maile (Ed.), Education and poverty reduction strategies: Issues of policy coherence, colloquium proceedings. Cape Town: HSRC Press.

Boughey, C. (2005) Epistemological access to the university: An alternative perspective. South African Journal of Higher Education, 19, 230-242. doi:10.4314/sajhe.v19i3.25516

Capazorio, B. (2011) Minister tackles rot at schools in Eastern Cape.
Sunday Independent, January 30.

Casadesus-Masanell, R., \& Ricart, J. E. (2011). How to design a winning business model. Harvard Business Review, January-February, 100-107.

Centre for Development and Enterprise (CDE) (2007). Doubling for growth: Addressing the maths and science challenge in South Africa's schools. Johannesburg: CDE.

Chikane, F. (2012). Eight Days in September: The removal of Thabo Mbeki. Johannesburg: Picador Africa.

Chisholm, L., Hoadley, U., Kivilu, M., Brooks, H., Prinsloo, C., Kgobe, A., Mosia, D., Narsee, H., \& Rule, S. (2005). Educator workload in South Africa. Cape Town: HSRC Press.

Chisholm, L. (2003). The politics of curriculum review and revision in South Africa. International Conference on Education and Development, 9-11 September.

Department of Education (DoE) (2007a). Ministerial committee on schools that work: Report to the minister of education. Pretoria: Department of Education.

Department of Education (DoE) (2007b). Ministerial committee on learner retention in the South African schooling system: Progress report to the minister of education Mrs. GNM Pandor, M.P. Pretoria: Department of Education.

Department of Education (DoE) (2000). The national policy on whole school evaluation. Pretoria: Department of Education.

Diko, N. N., \& Letseka, M. (2009). Policy appropriation in teacher retention and attrition: The case of North-West Province. Perspectives in Education, 27, 223-236.

Egan, K. (1992). The roles of schools: The place of education. Teachers College Record, 93, 641-655.

Enslin, P. (1993). Should nation-building be an aim of education? Inaugural Lecture Delivered at the University of the Witwatersrand, Johannesburg, 22 September 1993.

Feris, M. (2011). Rain stops classes at ruined schools. City Press, 30 January 2011.

Fiske, E. B., \& Ladd, H. F. (2004). Illusive equity: Education reform in post-apartheid South Africa. Cape Town: HSRC Press.

Fleisch, B. (2010). The politics of the governed: South African Democratic Teachers' Union Soweto strike, June 2009. South African Review of Education, 16, 117-131.

Fleisch, B. (2008). Primary education in crisis: Why South African schoolchildren underachieve in reading and mathematics. Cape Town: Juta \& Co.

Govindarajan, V., \& Trimble, C. (2011). The CEO’s role in business model reinvention. Harvard Business Review, January-February, 109-114.

Gauthier, C., \& Dembélé, M. (2004). Quality of teaching and quality of education: A review of research findings. Education for All Global Monitoring Report 2005. Paris: UNESCO.

Hammer, M., \& Champy, J. (2003). Reengineering the corporation: A manifesto for business revolution. New York: HarperCollins Publishers.

Hammer, M. (1996). Beyond reengineering: How the process-centered organization is changing our work and our lives. New York: Harper-Business.

Hammer, M. (1990). Reengineering work: Don’t automate, obliterate. Harvard Business Review, July-August, 2-8.

Harvard Business Review (2011). Spotlight: Business model innovation. Harvard Business Review, January-February, 79-114.

Hofmeyr, J., \& Oberholzer, A. (2011). A fair look at facts vs. fiction. The Star, 11 January 2011.

Jansen. J. (2004). Autonomy and accountability in the regulation of the teaching profession: A South African case study. Research Papers in Education, 19, 51-66. doi:10.1080/0267152032000176972

Joseph, R. (2003). Africa's predicament. Chronicle of Higher Education, 7 March 2003, B7-B10.

Kivilu, M. (2006). The matriculation examination: How can we find out if standards are falling. In V. Reddy (Ed.), Marking matric: Colloquium proceedings. Cape Town: HSRC Press.

Lall, S., \& Pietrobelli, A. (2002). Failing to compete: Technology development and technology systems in Africa. Cheltenham: Edward Elgar. 
Lelliott, J., \& Mbabela, Z. (2010). Matric exam strike threat. The Times, 25 August 2010.

Letseka, M. (2010). Early childhood development (ECD) trends in the province of the Eastern Cape, South Africa. Commonwealth Youth and Development, 8, 56-71.

Makola, C. P. (2005). Factors affecting teaching and learning in South African public schools. Education Labor Relations Council. Cape Town: HSRC Press.

Mbabela, Z. (2010). SADTU vows to shut schools. The Times, 4 August 2010.

Moll, I. (2004). Curriculum responsiveness: The anatomy of a concept. In H. Griesel (Ed.), Curriculum responsiveness: Case studies in higher education. Pretoria: SUAVCA.

Monana, T., \& Hlongwane, K. (2010). Strike violence muddies image of teachers. Sowetan, 30 August 2010.

Monare, M. (2010). Selfish power struggles standing black pupils. Pretoria News, 10 January 2010.

Moloi, M. Q. (2005). Mathematics achievement in South Africa: A comparison of the official curriculum with pupil performance in the SACMEQ II Project. SACMEQ International Invitational Conference, International Institute for Educational Planning. Paris: UNESCO, 28-30 September 2005.

Morrow, W. (1992). Epistemological access in university. $A D$, 1, 3-5.

Mosselson, M. (2008). What works in school development? JET Bulletin, 19, 1-6.

Nunes, P., \& Breene, T. (2011). Reinvent your business before it's too late: Watch out for those S curves. Harvard Business Review, January-February, 80-87.

Nyamapfene, K., \& Letseka, M. (1995). Problems of learning among first year students in South African Universities. South African Journal of Higher Education, 9, 159-167.

O’Looney, J. (1993). Redesigning the work of education. The Phi Delta Kappan, 74, 375-381.

Ray, M. (2008). Educashen crysis: Wanted: 68000 engineers/artisans.
Finweek, 7 February 2011.

Reddy, V., van der Berg, S., Lebani, L., \& Berkowitz, R. (2006). A trend analysis of matric performance. In V. Reddy (Ed.), Marking matric: Colloquium proceedings. Cape Town: HSRC Press.

SADTU (2006). SADTU Constitution, as amended in September 2006.

Shindler, J. (2008). Public schooling. In A. Kraak, \& Karen Press (Eds.), Human resource development review 2008: Education, employment and skills in South Africa. Cape Town: HSRC Press.

Slonimsky, L., \& Shalem, Y. (2006). Pedagogic responsiveness for academic depth. Journal of Education, 40, 35-58.

Taylor, N. (2006). Schools, skills and citizenship. JET Bulletin, 15, 2-3.

Taylor, N., Muller, J., \& Vinjevold, P. (2003). Getting schools working: Research and systematic school reform in South Africa. Cape Town: Maskew Miller Longman.

The Economist (2011). Briefing: Public-sector workers. The Economist, 8-14 January 2011.

The Economist (2010). A special report on South Africa: Last in class. The Economist, 3 June 2010.

The Star (2011). Editorial. The Star, 13 January 2011.

Van der Berg, S. (2008). How effective are poor schools? Poverty and educational outcomes in South Africa. Studies in Educational Evaluation, 34, 145-154. doi:10.1016/j.stueduc.2008.07.005

Van der Berg, S. (2007). Apartheid's enduring legacy: Inequalities in education. Journal of African Economies, 16, 849-880. doi:10.1093/jae/ejm017

Weber, E. (2005). New controls and accountability for South African teachers and schools: The integrated quality management system. Perspectives in Education, 23, 63-72.

Wilson, J. (1988). What philosophy can do for education? Canadian Journal of Education, 13, 83-91. doi:10.2307/1495168

Zengele, T. (2009). The involvement of teacher unions in the implementation of the employment of educators' act 76 of 1998 . Unpublished DEd Thesis, Pretoria: University of South Africa. 